\title{
Student Voice on the Personal Qualities of the Effective English Language Teacher:
}

\section{A Collective Case Study}

\author{
Ms. Corinne Vong \\ Lecturer, The Teacher Institute of Education, Sultan Abdul Halim Campus, Sungai Petani, \\ Kedah, Malaysia \\ Email: Corinne@malaysian-ghost-research.org
}

Dr. Mohamad Jafre Zainol Abidin

Senior Lecturer, TESOL at the School of Educational Studies, Universiti Sains Malaysia Email: jafre@usm.my

Accepted: July 12, 2012 Published: August 10, 2012

Doi:10.5296/jsr.v3i2.2070ＵRL: http://dx.doi.org/10.5296/jsr.v3i2.2070

\begin{abstract}
Personal qualities of the effective English language teacher illustrated by English language experts still surprisingly churned out average English language proficiency in a majority of tertiary Malaysian students. Thus, this qualitative collective case study aimed at finding out how far student voice agreed with expert opinion through the in-depth responses of three primary school pupils, three secondary school students and three undergraduate trainee teachers representative of above average, average and below average English language proficiency, on how each of them described the personal qualities of the effective English language teacher. In this regard, student voice was analyzed using triangulation based not only on the same topics discussed, but also on the review of literature. Interestingly, the findings disclosed that student voice still had something extra to contribute in determining the personal qualities of the effective English language teacher, with a touch of irony and constructive criticism on how such qualities of English language teachers/lecturers could still further improve so as to be more effective in the eyes of learners.
\end{abstract}

\section{Introduction}

What actually qualifies the personal qualities of the effective English language teacher? In this respect, managing students of varied motivations, individual backgrounds, as well as learning abilities which also demands maximized emotional labor as well as emotional work 
of the teacher - relies on the personal qualities of such a teacher, as discovered by Flores and Day (2006). In this regard, Isenbarger and Zembylas (2006) elaborated that emotional labor is how teachers, for the purpose of reflecting the caring nature of a teacher, have to induce, neutralize or inhibit their own feelings; while emotional work would require the said teachers to empathies with students. Thus, the personal qualities of the English language teacher considered effective include displaying care, humor and an understanding of others (Shaffer, 2009).

Yet, what defines the personal qualities of the effective English language teacher has been heavily described by English language experts, namely English language teachers and English language lecturers well-versed in the language who are considered to know the ins and outs of such qualities that befit the role model English language teacher/lecturer; yet, too little attention has been paid to student voice on the issue. Whatever the reasons for the lack of past research to investigate student voice on personal qualities of the effective English language teacher, the researcher believes it is crucial that the definition for such a teacher should equally include valuable descriptive feedback from student voice - lest this definition be far too dependent on solely expert opinion. Therefore, the researcher is interested to investigate how far student voice has agreed with the personal qualities of the effective English language teacher outlined by expert opinion, in order for newer insights discovered to be added on to the pool of expert interpretation on the same topic, because after all, it is only when the English language teacher/lecturer is actually able to cater to the learning needs as outlined by student voice itself - that the aforementioned teacher's/lecturer's effectiveness be duly acknowledged.

\section{Statement of the Problem}

To date, experts of the English language have described all that needs to be internalized of the kind of personal qualities the effective English language teacher is expected to possess, as a perfect reference for all those teaching the language to be able to motivate and inspire students on towards greater heights of English language excellence. Surprisingly instead, the English language proficiency of a majority of tertiary Malaysian students is still very much mediocre and not the targeted excellent, as displayed in the table below. This discovery was surprising, as the English language lecturers in Institute of Teacher Education Y (ITE Y) are well trained to encourage student learning of the English language, while its undergraduate trainee teachers were among the best selected post-Sijil Pelajaran Malaysia students throughout the country to follow the newly introduced degree programme in institute of teacher educations nationwide. In this respect, since English cannot be mastered overnight, the question at hand was, why was the performance of the aforementioned undergraduate trainee teachers in the English language proficiency paper severely short of being excellent, as portrayed by only thirteen of these undergraduate trainee teachers having outshone their counterparts, despite those undergraduate trainee teachers having had been under the tutelage of teachers who had taught them English during a period of at least ten to eleven years? 
The comparison of English Language Proficiency II grades among first year undergraduate trainee teachers in their second semester of Institute of Teacher Education Y in Kedah.

\begin{tabular}{|c|c|c|c|c|c|c|c|c|c|c|c|}
\hline \multirow{5}{*}{$\begin{array}{l}\text { English } \\
\text { language } \\
\text { lecturer }\end{array}$} & \multirow{5}{*}{$\begin{array}{l}\text { Year } \\
1 \\
\text { Sem } \\
2 \\
\text { Class }\end{array}$} & \multirow{5}{*}{$\begin{array}{l}\text { No. of } \\
\text { under-gra } \\
\text { duate } \\
\text { trainee } \\
\text { teachers }\end{array}$} & \multicolumn{9}{|c|}{ English Language Proficiency II Grades } \\
\hline & & & D & C- & $\mathbf{C}$ & $\mathbf{C +}$ & B- & $\mathbf{B}$ & $\mathbf{B +}$ & A- & \multirow[t]{3}{*}{$\mathbf{A}$} \\
\hline & & & + & & & & & & & & \\
\hline & & & & & & & & & & & \\
\hline & & & \multicolumn{2}{|c|}{ Weak } & \multicolumn{2}{|c|}{ Average } & & & Good & \multicolumn{2}{|c|}{$\begin{array}{l}\text { Very } \\
\text { Good }\end{array}$} \\
\hline Lecturer 1 & A & 19 & 1 & 2 & 4 & 4 & 1 & 5 & 2 & 0 & 0 \\
\hline Lecturer 2 & $\mathrm{~B}$ & 20 & 0 & 0 & 2 & 6 & 8 & 4 & $\mathbf{0}$ & $\mathbf{0}$ & $\mathbf{0}$ \\
\hline Lecturer 3 & $\mathrm{C}$ & 21 & 0 & 1 & 8 & 6 & 6 & 0 & 0 & 0 & $\mathbf{0}$ \\
\hline Lecturer 4 & $\mathrm{D}$ & 20 & 0 & 3 & 1 & 4 & 6 & 6 & 0 & 0 & $\mathbf{0}$ \\
\hline Lecturer 5 & $\mathrm{E}$ & 18 & 0 & 0 & 0 & 0 & 2 & 11 & 5 & 0 & $\mathbf{0}$ \\
\hline Lecturer 4 & $\mathrm{~F}$ & 18 & 1 & 0 & 2 & 3 & 4 & 2 & 2 & 3 & 1 \\
\hline \multicolumn{2}{|c|}{$\begin{array}{l}\text { Total no. of } \\
\text { undergraduate } \\
\text { trainee teachers }\end{array}$} & 116 & 2 & 6 & 17 & 23 & 27 & 28 & 9 & 3 & 1 \\
\hline
\end{tabular}

(November 2008)

Source: Adapted from ITE Y's Examinations Unit

Therefore, the problem which arises is - English language teachers in primary and secondary schools, as well as English language lecturers in institute of teacher educations have all the input from English language experts worldwide on how to become effective in terms of personal qualities - and yet, the majority of some of the best Malaysian students in general represented by the sample in ITE Y, still fail to excel in English.

\section{Objective of the Study}

The objective of the study is to find out how far student voice agrees with the description by expert opinion on the personal qualities of the effective English language teacher.

\section{Research Question}

Based on the aforementioned objective, the researcher in this study attempts to answer the following research question:

How far does student voice agree with the description by expert opinion on the personal 
qualities of the effective English language teacher?

\section{Related Literature}

Expert opinion had outlined qualities of the effective English language teacher which included avoiding student favoritism (Celce-Murcia, 2002; Cowley, 2003; Cruickshank, Jenkins, \& Metcalf, 2003; Hart, 2007; Khalid Al Seghayer, 2006-2007; Lajcak, 2002; Marshall, 2002; Vadillo, 2000); maintaining a good teacher-student relationship through knowing student names (Kyriacou, 1986; Martin, 2007), being caring or strict towards students (Brophy and Evertson, 1976; Garcia,1991; Glasser,1986); being close to students of the opposite sex (Celce-Murcia, 2002; Dixie, 2003; Kyriacou, 1986; Younger \& Warrington,1999); maintaining humour (P. J. Cooper and Simonds, 1999; Cowley, 2003; Cruickshank et al., 2003; Cullingford, 1995; Dixie, 2003; Glasser, 1986; Hasenstab, 1971; Kizlik, 2007; "Primary Teaching," 2007; Spelleri, 2002; Vadillo, 2000); managing student behavior (Cowley, 2003; Cruickshank et al., 2003; De Cremer, 2006; Dixie, 2003; "English Teacher," 2007; Fried, 2002; Kizlik, 2007, Kyriacou, 1986; Martin, 2007; Olsen \& P. Cooper, 2001; Vadillo, 2000; Wong \& Wong, 2005a; Wong \& Wong, 2004b); as well as believing in the potential of students and inspiring them on (Brophy \& Evertson,1976; Brophy \& Kher, 1986; Burke, Stagl, Klein, Goodwin, Salas \& Halphin, 2006; Claxton, 2007; Collins, 1986; Cowley, 2003; Dixie, 2003; Fried, 2002; Kohn, 2005; Kupka, 2006; Kyriacou, 1986; Murray, 2002; Vadillo, 2000; Wong \& Wong, 2006; Wong \& Wong, 2001a; Younger \& Warrington,1999).

\section{The Research Methodology}

The research design for this particular study - a collective case study - involved student voice on the personal qualities of the effective English language teacher coming from three research participants in a primary school in the Kedah State, three research participants in a secondary school in the Kedah State as well as three research participants in an institute of teacher education in the Penang State of above average, average, and below average English language proficiency respectively, based on the recommendations of their English language teachers/lecturers, and who were total strangers to the researcher.

In this respect, the researcher utilized the interview of five semi-structured interview questions for each of the child, adolescent, and young adult categories - on issues expounded by expert opinion in the literature review based on five thematic headings of the personal qualities of the effective English language teacher - with the help of a tape recorder, after the interview questions had firstly been scrutinized by three English language experts; and secondly, after the interview questions were refined based on a pilot test being carried out on individuals other than the research participants of the study, so as to increase the chances of success of the impending actual research to be carried out. 
Hence, such a study was to find out if certain generalizations could be made through student voice coming from children in the primary school, adolescents in the secondary school, and young adults in the institute of teacher education regarding their description of the personal qualities of effective English language teacher, which is to complement expert opinion on the matter.

\section{Research Findings}

Student voice which agreed with expert opinion on the effective English language teacher's/lecturer's need to avoid student favoritism provided reasons not elaborated by expert opinion, which included pupils and students not only liking the teacher to shower attention on them alone but on other pupils/students as well, or risk being compared with other teachers in negative light by pupils; while undergraduate trainee teachers good in English and favored by a lecturer may not be just as flawless in character. Meanwhile, there were other reasons not mentioned by expert opinion offered by student voice against the teacher's/lecturer's show of student favoritism, such as pupils/undergraduate trainee teachers not in the teacher's/ lecturer's favor becoming jealous of their more favored counterparts, resulting in the badmouthing and out casting of lecturers' favorites; as well as students feeling saddened or feel being beneath other students. However, in contrast with expert opinion, student voice not in support of the lecturer's need to avoid student favoritism argued that the undergraduate trainee teachers who were not the lecturer's favorite were happy not to be the focus of attention and did not have to be singled out to conduct numerous activities, and could therefore do the things they liked to instead.

Moreover, in order to maintain a good teacher-student relationship, student voice in elaboration to what has been mentioned by expert opinion maintained the effective English language lecturer/teacher needed to know student names to enable undergraduate trainee teachers/pupils to feel acknowledged as a person; as well as to enable the teacher to remember pupils' names and not to address students using peculiar names if the teacher were to forget their names. Yet interestingly, student voice which contrasted expert opinion regarding the necessity of the teacher/lecturer to know student names reasoned that when student names were known, students feared being observed for their every mistake made; similarly, undergraduate trainee teachers who liked to remain anonymous actually did not want to answer the lecturer's questions when they did not know the answers, for they did not liked being laughed at by the whole class instead.

Furthermore, with regard to maintaining a good teacher-student relationship, student voice, to elaborate what has been put forth by expert opinion, insisted that the need to be strict by the effective English language teacher/lecturer was when pupils failed to do their homework or prepare for their spelling, when students did not do their work, and when the lecturer was being strict towards undergraduate trainee teachers out of concern for them. Nevertheless, in contrast with expert opinion, student voice against the need for the teacher/lecturer to be strict was 
because pupils/students feared such a teacher to the point of being scared all the time and thus were compelled to be voiceless in class, feel distant from the teacher, as well as were unable to study and just felt like wanting to go home; while undergraduate trainee teachers would despise the lecturer who punished them without concrete reasons which would then make it difficult for the lecturer to teach them after that. At the same time, also pertaining to maintaining a good teacher-student relationship, student voice further elaborated on what has been mentioned by expert opinion that the effective English language teacher/lecturer needed to be caring towards pupils so as to be popular with them and not simply cane them; to enable pupils/students to learn English easily and encourage students to be more vocal in class; as well as to motivate undergraduate trainee teachers to be better individuals and to be supportive towards them in terms of care and knowledge.

In addition, still with reference to maintaining a good teacher-student relationship, student voice in elaboration to what has been proposed by expert opinion, felt that effective English language lecturers needed to avoid being intimately close to undergraduate trainee teachers of the opposite sex in order to prevent chemistry between the two parties from triggering off that might lead them to be caught indecently; similarly, student voice did not think highly of lecturers flirting with undergraduate trainee teachers as well as thought it improper for the trainee teachers concerned to reciprocate such advances of those lecturers. Interestingly however, student voice in contrast with expert opinion on this matter actually saw nothing amiss with the effective English language teacher's/lecturer's being close to pupils/students/undergraduate trainee teachers of the opposite sex, as pupils/students considered it a chance for the teacher to be friendly towards them regardless of sex; pupils saw it as an opportunity for the teacher to teach them more; students themselves regarded the role of male teachers as father figures or friends towards female students; while undergraduate trainee teachers found the close interaction of a lecturer and an undergraduate trainee teacher of the opposite sex most healthy, whether the interaction was on a counseling basis or even if the interaction were to result in the lecturer and undergraduate trainee teacher concerned were to lead to marriage.

Moreover, even though student voice complimented expert opinion on the need for the effective English language teacher/lecturer to maintain humour, it offered additional reasons for such humour to be maintained, such as preventing pupils from dozing off during lessons and lessening student boredom, as well as lessening undergraduate teachers' tension and enabling them to remember hilarious examples used by the lecturer. Yet, student voice also elaborated on what was mentioned by expert opinion, in that some students felt that the effective English language teacher needed to use humour in the classroom only when the lesson proved very dull, lest they also not take the lesson seriously.

Furthermore, in the case of managing student behavior when a pupil/student/undergraduate trainee teacher was late for English class, although student voice agreed with expert opinion about the effective English language teacher needing to admonish the pupil who had no acceptable reason for being late, it also had differing views from those of expert opinion, in 
that the English language lecturer, rather than shout at the undergraduate trainee teacher and souring the whole class atmosphere, needed to instead talk to the latter on a one-to-one basis in order to understand the real reason behind the lateness. In addition to what has been mentioned by expert opinion, student voice also felt the teacher needed to excuse pupils who were on a bus that arrived late, or if their reasons for being late were logical.

Nevertheless, in elaboration to what has been advocated by expert opinion, student voice saw punitive measures by the effective English language teacher/lecturer meant to manage student behavior in the aforementioned situation as justified for the student/undergraduate trainee teacher being inexcusably late, that included subjecting the student to more written work; getting the student to produce correct answers to lots of English questions before being allowed to sit down at one's place in class; making the student stand in front of the class as a lesson to learn for being late; lecturing the undergraduate trainee teacher about being late rather than disallowing the latter from class entry, or finally sending the latter who was recurring late to the Student Affairs Division in order to be seen by the other undergraduate trainee teachers as being firmer at handling the situation.

Additionally, in the case of managing student behavior when a student was disrespectful towards the effective English language teacher, student voice differed slightly from expert opinion, in that even though students felt that the teacher needed to be cool and controlled when handling a misbehaving student, they still preferred that the situation needed to be dealt with away from the rest of the class. Nonetheless, to add on to what has been mentioned by expert opinion, student voice revealed two contrasting situations in which how the misbehaving undergraduate trainee teachers could actually improve in order to become better persons, that is firstly, the effective English language lecturer needed to have private discussions with them rather than subject them to public humiliation that would only trigger off their hatred towards the lecturer instead; and secondly, the lecturer out of one's responsibility needed to gently but directly pointed out the undergraduate trainee teacher's misconduct. Yet, in elaboration to what has been mentioned by expert opinion, student voice disclosed how some students not only sanctioned the need for the teacher to get angry with a disrespectful student, but some pupils also saw it befitting of the teacher to publicly cane the pupil for not respecting the teacher.

Interestingly however, student voice also advocated that the effective English language teacher needed to utilize advice over punitive measures when managing student behavior for both the aforementioned cases, which was totally not mentioned by expert opinion. In this regard, student voice suggested that the teacher both needed to advise the pupil to come earlier for class in future, rather than to continuously inflict physical punishment on the pupil and be disliked for it, as the pupil also has feelings.

Finally, student voice, in elaboration of what had been mentioned by expert opinion about the need for the effective English language teacher/lecturer to believe in the potential of students and to inspire them on, such belief of this kind of teacher which made pupils feel good and 
cared for actually encouraged them to put more effort in their studies; students perceived such a teacher as not only hiking up their self-worth, but also their confidence and motivation levels for them to improve their English; while undergraduate trainee teachers felt such a lecturer's encouraging words inspired them on to believe in their own potential to be a truly good English language teacher, or a better person in future as a result of bettering their command in the language. Yet interestingly, student voice in contrast with expert opinion also reveled that some undergraduate trainee teachers never have had any English language lecturers who had motivated them, perhaps because of their quieter nature, and therefore they ended up banking on family support instead.

\section{Implications of the Research Findings}

To be effective based on personal qualities, student voice implies that it is necessary that the English language teacher/lecturer avoids student favoritism in order not to be criticized by pupils and to realize that a favorite of the lecturer may not be as outstanding in terms of character; in order to prevent unhealthy jealousy not only amongst pupils but also amongst insecure undergraduate trainee teachers, whereby the lecturer's favorite will be cursed or alienated by the non-favorites; as well as in order to prevent students weak in English from being de-motivated to improve in their English, in the same way it would prevent quiet students from feeling lowly amongst their peers. In contrast with expert opinion however, student voice which did not mind the English language lecturer's display of open student favoritism interestingly implies that the effective English language may require to also recognize how some undergraduate trainee teachers may not actually mind the lecturer having student favorites other than themselves whom they are not at all envious of, as they are happier off not being in the limelight.

Moreover, student voice suggests that the effective English language teacher/lecturer indeed needs to know student names, so as to acknowledge pupils/students/undergraduate trainee teachers as persons of identity. Nevertheless, student voice in contrast with expert opinion also indicates that the effective English language teacher/lecturer would be expected to understand that some students/undergraduate trainee teachers prefer to reserve their identities from the teacher/lecturer, as a result of their becoming scared or uncomfortable at being observed for their every mistake and blunder made in their learning of English.

Furthermore, student voice implies that the effective English language teacher indeed needs to be strict towards students. This is because, student voice additionally hints that the strict nature of the effective English language teacher is for the sake of preventing student failures in English; and that the teacher has every right to punish pupils/students for not doing given work. However, student voice in contrast with expert opinion about students liking a strict English language teacher, suggests that the effective English language teacher/lecturer needs to avoid being strict in order not to be disliked by all pupils; not to be feared by pupils as a result of caning them if the class was noisy; not to be feared by pupils to the point that it hampers their ability to study English well; not to rid students of their voice and thus 
jeopardize teacher-student communication; not to be feared by students to the extent the latter want to return home; as well as not to be hated by unforgiving undergraduate trainee teachers penalized for non-concrete reasons - who will later become a problem to teach. In this way, while student voice also agreed with expert opinion about the effective English language being caring towards students, indicating the necessity of the effective English language teacher/lecturer to indeed be caring towards pupils/students/undergraduate trainee teachers, student voice additionally implies that in order to prove effective, the English language teacher/lecturer has to be one who is popular with pupils; one who refrains from simply caning pupils; one who enables pupils/students to easily absorb what is taught; one who entertains questions of students; as well as one who morally supports undergraduate trainee teachers and wants them to improve as persons.

Additionally, student voice suggests that the effective English language teacher/lecturer indeed does need to be aware of the dangers of being close to students/undergraduate trainee teachers of the opposite sex; yet, student voice however implies that the effective English language teacher/lecturer could also maintain such a relationship on a platonic plain perfectly healthy for both parties. Taking a step further, in total contrast with expert opinion, student voice also additionally hints that the effective English language teacher/lecturer should not avoid having a close teacher-pupil/teacher-student/lecturer-undergraduate trainee teacher relationship of the opposite sexes. This is because, pupils/students themselves see it as actually healthy that the teacher maintains a good relationship with pupils/students - boys and girls alike, for even some female students regard their male teachers as father figures or friends; and even if the lecturer and undergraduate trainee teacher of the opposite sexes were to progress from a platonic friendship to a marital stage, some undergraduate trainee teachers see it simply as both parties being fated for each other.

Not to be forgotten, student voice generally indicated that the effective English language teacher/lecturer indeed needs to maintain humour during lessons, which was necessary to effectively enable pupil/student focus, as well as to dispel tension and the dread of boredom, besides enabling better memory retention in undergraduate trainee teachers. Nevertheless, student voice also implies that the effective English language teacher indeed needed to maintain humour in the classroom, but to not overdo it, because as student voice additionally hints, even though the English language teacher's jokes are effective to enhance a dull lesson, the teacher has to control overly cracking jokes when teaching that might result in some students equally taking light of their English learning.

Moreover, pertaining to managing student behavior when a pupil/student/undergraduate trainee teacher was late for class, student voice implies that the effective English language lecturer needs to both personally and amicably find out reasons behind the undergraduate trainee teacher's lateness, as well as to excuse pupils/students who have valid reasons for being late. Furthermore, even though the effective English language teacher/lecturer indeed is expected to utilize one's power accordingly, in order to manage student behavior where lateness for lessons was concerned, student voice additionally suggests that the effective 
English language teacher/lecturer ought to subject the deliberately late student with more written work, answering English questions correctly, and standing at the front of the class; or to admonish the deliberately late undergraduate trainee teacher, or to further leave punishment at the hands of the Student Affairs Division - in order to drive home the message that such lateness was not to be encouraged nor tolerated by the teacher/lecturer.

In the same way, student voice, besides hinting that the effective English language teacher/lecturer indeed needs to address disrespectful students/undergraduate trainee teachers in a more mature-like fashion, with regard to managing student behavior, it additionally suggests that such a tactic by the teacher/lecturer would help the misbehaving student/undergraduate trainee teacher to be moulded into a more improved individual. However, in agreement with expert opinion on the English language teacher's use of punitive measures, indicating that it is necessary for the effective English language teacher to also utilize punishment when managing student behavior, student voice additionally implies that in order to effectively take stock of the situation, the English language teacher also has the right to publicly cane the disrespectful pupil in front of the class, as a strong message against intolerable behavior.

Yet, student voice additionally hints that the effective English language teacher could also consider using advice over punishment when dealing both with the pupil who is late, as well as the disrespectful pupil, for such pupils are individuals equally not devoid of feelings, and thus require non-punitive guidance instead.

Besides that, student voice suggests that the effective English language teacher/lecturer indeed needs to believe in the potential of students and to inspire them on. Furthermore, student voice additionally implies that the effective English language teacher/lecturer is expected to realize that such belief and inspiration make pupils/students/undergraduate trainee teachers feel good, cared for, confident and motivated to learn English; as well as believe in their own potential to be successful in their career and as a person. However, student voice also hints that should the English language lecturer fail to effectively display belief in the potential of undergraduate trainee teachers nor inspire them, it would result in some of these trainee teachers still able to manage - but only through confidence and support from their own selves and family.

\section{Conclusion}

The implications of the findings of this study indeed point out that no matter how much student voice tallies with expert opinion on personal qualities of the English language teacher/lecturer deemed effective, it still has something extra to contribute in determining the effective English language teacher. This is not in the least surprising, considering that pupils, students and undergraduate trainee teachers are thinking individuals in their own right. Very interestingly too, the responses of the nine participants often tallied with one another, irrespective of their age group nor English language proficiency command - as each of them could actually help determine the kind of English language teacher/lecturer they considered 
effective enough for them to be able to be comfortable with, in their quest to master the English language. After all, any problems revolving round the teaching and learning of English are the consequence of mismatched expectations of both the English language teacher/lecturer and their pupils/students/undergraduate trainee teachers.

Therefore, student voice is indeed crucial in providing a channel for pupils/students/undergraduate trainee teachers alike to be bold enough to tell the experts of the English language that if they were to expect any English language teacher/lecturer to be hailed as truly effective, then what it expects of the effective English language teacher equally needs to be heard, considered, internalized and acted upon accordingly by all English language teachers/lecturers at large. Thus, this to a certain extent calls for the reassessment personal qualities of the English language teacher/lecturer because if left ignored, such vital information would cause English language teachers/lecturers to fall short of ever becoming the effective English language teacher in its truest sense of the word.

Thus, delving into the minds of pupils/students and undergraduate trainee teachers provides a rare opportunity for the researcher to seek the missing link as to what is really expected by student voice of the personal qualities of the effective English language teacher as its contribution to existing expert opinion on the matter, which finally serves as a more complete reference for all interested parties on the description of - the effective English language teacher.

\section{References}

Brophy, J., \& Kher, N. (1986). Teacher socialization as a mechanism for developing student motivation to learn. In R. S. Feldman (Ed.), The social psychology of education (pp. 257-288). Cambridge: Cambridge University Press.

Brophy, J. E., \& Evertson, C. M. (1976). Learning from teaching: A developmental perspective. Boston: Allyn and Bacon, Inc.

Burke, C. S., Stagl, K. C., Klein, C., Goodwin, G. F., Salas, E., \& Halphin, S. M. (2006). What type of leadership behaviours are functional in teams? A meta-analysis. The Leadership Quarterly, 17 (3), 288-307.

Celce-Murcia, M. (2002). A career dedicated to enlightening ESL teachers. 2002 ESL MiniConference Online. Retrieved July 4, 2007, from http://www.eslminiconf.net/april/celcemurcia.html

Claxton, G. (2007). Expanding young people's capacity to learn. British Journal of Educational Studies, 55 (2), 115-134.

Collins, N. (1986). New teaching skills. Oxford: Oxford University Press.

Cooper, P. J., \& Simonds, C. (1999). Communication for the classroom teacher (6th ed.). Needham Heights, MA: Allyn \& Bacon. 
Cowley, S. (2003). Sue Cowley's teaching clinic. London: Continuum.

Cruickshank, D., Jenkins, D. B., \& Metcalf, K. K. (2003). The act of teaching (3rd ed.). New York: McGraw-Hill.

Cullingford, C. (1995). The effective teacher. London: Cassell.

De Cremer, D. (2006). Affective and motivational consequences of leader self-sacrifice: The moderating effect of autocratic leadership. The Leadership Quarterly, 17 (1), 79-93.

Dixie, G. (2003). Managing your classroom. London: Continuum.

English teacher: Secondary job analysis of physical, mental, and emotional demands. (2007). Teacher Education. Retrieved March 21, 2007, from http://education.byu.edu/ted/pdf/secondary.pdf

Flores, M. A., \& Day, C. (2006). Contexts which shape and reshape new teachers' identities: A multi-perspective study. Teaching and Teacher Education, 22 (2), 219-232.

Fried, R. L. (2002). The passionate teacher: A practical guide. Harvard Educational Review, $72(1), 564-568$.

Garcia, E. E. (1991). Effective instruction for language minority students: The teacher. Journal of Education, 173 (2), 130-141.

Glasser, W. (1986). Choice theory in the classroom (rev. ed.). New York: HarperCollins Publishers Inc.

Hart, G. (2007). What makes a good English teacher? Socyberty. Retrieved December 15, 2008 ,

from http://www.socyberty.com/Education/What-Makes-a-Good-English-Teacher--.47949

Hasenstab, J. K. (1971). Characteristics of effective teachers. Performance Learning Systems : The Heart of Teaching Issue 79. Retrieved February 26, 2007, from http://www.plsweb.com/resources/newsletters/hot_archives/79/effective_teacher/

Isenbarger, L., \& Zembylas, M. (2006). The emotional labour of caring in teaching. Teaching and Teacher Education, 22 (1), 120-134.

Khalid Al Seghayer. (2006-2007). Characteristics of good English instructors. ESL Elite. Retrieved December 12, 2008, from http://search4.incredimail.com/?q=profile+of+effective+english+teachers\&lang=english 
$\underline{\text { ssource }=001043051011 \& \mathrm{p}=2}$

Kizlik, B. (2007). Tips on becoming a teacher. Adprima Site Directory. Retrieved February 22, 2007, from http://www.adprima.com/tipson.htm

Kohn, A. (2005). Unconditional teaching. Educational Leadership, 63 (1), 20-24.

Kupka, M. (2006). English teacher philosophy of teaching is all about a student's progress. Teaching English Tips. Retrieved March 22, 2007, from http://www.teachingenglishtips.com/resources/philosophy-of-teaching.html

Kyriacou, C. (1986). Effective teaching in schools. Oxford : Basil Blackwell Ltd.

Lajcak, R. (2002). Conveying the excitement of ESL to teachers-in-training. 2002 ESL MiniConference Online. Retrieved July 4, 2007, from http://www.eslminiconf.net/april/lajcak.html

Marshall, L. (2002). Setting high standards, guiding with sensitivity. 2002 ESL MiniConference Online. Retrieved July 4, 2007, from http://www.eslminiconf.net/june/marshall.html

Martin, D. (2007). How to be an effective EFL teacher. EFL Press. Retrieved March 21, 2007, from http://www.eflpress.com/how_to_be_an_effective_efl.html

Murray, D. E. (2002). Mediating choice and access for ESL learners. 2002 ESL MiniConference Online. Retrieved July 4, 2007, from http://www.eslminiconf.net/august/murray.html

Olsen, J., \& Cooper, P. (2001). Dealing with disruptive students in the classroom. London: Kogan Page Limited.

Primary teaching: Characteristics of a good teacher. (2007). Teaching@ DE\&T. Retrieved February 22, 2007, from http://www.teaching.vic.gov.au/becometeach/primary/character.htm

Shoffner, M. (2009). The place of the personal: Exploring the affective domain through reflection in teacher preparation. Teaching and Teacher Education, 25 (6), 783-789.

Spelleri, M. (2002). An enthusiastic passion for the ESL calling. 2002 ESL MiniConference Online. Retrieved July 4, 2007, from http://www.eslminiconf.net/june/spelleri.html 


\section{Macrothink}

Journal of Sociological Research

ISSN 1948-5468 2012, Vol. 3, No. 2

Vadillo, R. S. M. (2000). Some hints for the English language teacher. Instituto Superior de Formación y Recursos en Red para el Profesorado. Retrieved December 16, 2008, from http://search4.incredimail.com/?q=profile+of+effective+english+teachers\&lang=english $\underline{\text { source }=001043051011 \& \mathrm{p}=2}$

Wong, H., \& Wong, R. (2001a). Effective teaching: A journey of the heart. teachers.net. Retrieved February 23, 2007, from http://teachers.net/gazette/FEB01/wong.html

Wong, H., \& Wong, R. (2004b). Effective teaching: What to do when they complain. teachers.net. Retrieved February 23, 2007, from http://teachers.net/wong/APR04/

Wong, H., \& Wong, R. (2005a). Effective teaching: Classroom management is not discipline. teachers.net. Retrieved February 23, 2007, from http://teachers.net/wong/OCT05/

Wong, H., \& Wong, R. (2006). Effective teaching: They're eager to do the assignments. teachers.net. Retrieved February 23, 2007, from http://teachers.net/wong/APR06/

Younger, M., \& Warrington, M. (1999). 'He's such a nice man, but he's so boring, you have to really make a conscious effort to learn': The views of Gemma, Daniel and their contemporaries on teacher quality and effectiveness. Educational Review, 51 (3), 231-241. 